\title{
Iran, Islamic Republic of
}

National Cancer Institute

\section{Source}

National Cancer Institute. Iran, Islamic Republic of. NCI Thesaurus. Code C16755.

A country in the Middle East, bordering the Gulf of Oman, the Persian Gulf, and the Caspian Sea, between Iraq and Pakistan. 